\title{
Studi Histomorfometri Ovarium Kambing Peranakan Etawah
}

\author{
(HISTOMORPHOMETRY STUDY OF ETAWAH CROSSBREED GOAT OVARY) \\ I Gede Erik Juliarta ${ }^{1 *}$, Ni Ketut Suwiti ${ }^{2}$, Ni Luh Eka Setiasih ${ }^{2}$ \\ ${ }^{1}$ Praktisi Dokter Hewan di Kecamatan Dauhwaru Jembrana- Bali; \\ ${ }^{2}$ Laboratorium Histologi Fakultas Kedokteran Hewan Universitas Udayana, Jln. PB. \\ Sudirman Denpasar-Bali \\ *Email: erick.cool62@yahoo.com
}

\begin{abstract}
Abstrak
Penelitian histomorfometri ovarium kambing Peranakan Etawah (PE) telah dilakukan. Sebanyak 64 ovarium kiri dan kanan dari kambing PE umur dewasa (12-36 bulan) dan muda (5-12 bulan) diambil dari Rumah Potong Hewan Kampung Jawa di Denpasar. Selanjutnya dibuat preparat histologi dan diwarnai dengan metode Harris - Hematoksilin Eosin. Hasil penelitian menunjukan struktur histologi ovarium terdiri dari lapisan korteks dan medulla. Pada lapisan korteks ditemukan perkembangan folikel dan pada lapisan medulla terdapat pembuluh darah, jaringan ikat longgar dan saraf. Tidak ada perbedaan jumlah folikel pada kambing dewasa dan muda. Tidak ada perbedaan $(\mathrm{P}>0,05)$ korteks maupun medulla ovarium kanan dan kiri. Korteks dan medulla ovarium kambing $\mathrm{PE}$ dewasa lebih tebal $(\mathrm{P}<0,05)$ dibandingkan muda.
\end{abstract}

Kata kunci: Kambing peranakan etawah; ovarium; histomorphometri.

\begin{abstract}
The histomorphometry study of Etawah crossbreed ovaries has been carried out. A total of 64 left and right ovaries from PE goats at aged (12-36 months) and young (5-12 months) were taken from the Kampung Jawa Slaughterhouse, in Denpasar. Then next is made histological preparations and stained with Harris - Hematoxylin Eosin. The results showed that the histological structure of the ovary consisted of cortical and medullary layers, respectively. In the cortex layers were found follicular development, and there are blood vessels, loose connective tissue, and nerves in the medulla layers. There is no difference in the number of follicles in adult and young goats. There were no differences $(\mathrm{P}>0.05)$ of the right and left of the cortex and ovarian medulla. The ovarian cortex and medulla of adult $\mathrm{PE}$ goats are thicker $(\mathrm{P}<0.05)$ than a young.
\end{abstract}

Keywords: Etawah crossbreed goat; ovary; histomorphometry.

\section{PENDAHULUAN}

Kambing merupakan salah satu hewan ternak yang dipelihara di pedesaan dan perkotaan, baik di dataran rendah maupun dataran tinggi di Indonesia. Populasi kambing semakin banyak, ditinjau dari segi jenisnya: salah satunya adalah kambing peranakan etawah sebagai tipe pedaging dan produksi susu (Yoyo et al., 2013). Kambing dipelihara dengan kepemilikan dua sampai lima ekor (Djajanegara dan Setiadi, 1991). Pertumbuhan populasi menunjukan angka yang terus meningkat sebesar (3,3\%) (Direktorat Jendral dan Kesehatan Hewan, 2016).
Peternakan kambing di Indonesia memiliki potensi yang cukup besar untuk dikembangkan. Dengan adanya potensi tersebut, memicu peternak untuk beternak kambing dengan melakukan peningkatan dari segi manajemen pemeliharaan terutama pada manajemen reproduksi. Peternakan kambing di Bali kebanyakan menggunakan sistem perkawinan alami untuk meningkatkan produksi, sehingga peternakan diharuskan memiliki bibit unggul baik dari pejantan maupun dari betina.

Pengetahuan tentang reproduksi pada kambing khususnya peranakan etawah di 
Bali masih terbatas dan penting diketahui oleh peternak karena erat kaitannya dengan pengembangan suatu ternak. Tanpa pengetahuan tentang reproduksi maka, upaya-upaya budidaya dan pengembangan suatu ternak dipastikan tidak akan berhasil (Sutama, 2011).

Pertimbangan penilaian sistem reproduksi adalah menetapkan status reproduksi dan mengevaluasi siklus birahi hewan. Penyimpangan atau kelainan reproduksi dipredisposisi oleh umur. Semakin tua umur hewan, maka kelainan reproduksi semakin sering terjadi (Choliq et al, 2014).

Organ reproduksi kambing jantan dan betina berperan penting untuk keberhasilan mempertahankan suatu keturunan dan keanekaragaman agar tidak punah. Kualitas organ reproduksi ditentukan oleh struktur dan morfologi yang akan berkaitan dengan status fisiologis. Sifat-sifat reproduksinya sangat penting terkait dengan dewasa kelamin, tingkah laku kawin terutama karakteristik organ reproduksi betina. Informasi tersebut merupakan dasar yang seharusnya diketahui dalam upaya untuk mengembangkan dan menghindari kepunahan kambing (Sutama, 2011).

Organ reproduksi kambing betina terdiri dari ovarium, tuba fallopi, oviduct, uterus, vagina, serviks, vulva, klitoris. Salah satu organ reproduksi kambing peranakan etawah betina yang sangat penting adalah ovarium. Ovarium merupakan organ primer dan sangat penting pada betina. Ovarium sebagai kalenjar eksokrin dan endokrin yang menghasilkan ovum (sel telur) dan mensekresi hormon progesteron dan estrogen, dimana hormon ini sangat penting dan bertanggung jawab untuk proses reproduksi (Dellman dan Esther, 1992).

Sejauh ini belum ada kajian histomorfometri organ reproduksi khususnya ovarium kambing peranakan etawah. Sehingga perlu dilakukan penelitian yang dapat memberikan informasi tentang struktur histologi beserta ukurannya.

\section{METODE PENELITIAN}

Sampel ovarium yang digunakan dalam penelitian ini diambil dari kambing peranakan etawah di pemotongan hewan Kampung Jawa Denpasar. Sampel yang digunakan dibedakan atas umur dewasa (12-36 bulan), muda (5- 12 bulan) (Edey, 1993; SNI 7352, 2015) dan ovarium kanan dan kiri. Sehingga seluruh sampel yang diambil berjumlah 64. Sampel dimasukan ke dalam botol yang berisi larutan formalin $10 \%$ yang telah diberikan label.

Jenis penelitian yang dilakukan adalah jenis penelitian dengan metode deskriptif. Rancangan penelitian menggunakan rancangan acak lengkap pola faktorial menggunakan dua faktor umur (dewasa dan muda) dan posisi (kanan dan kiri). Penentuan jumlah sampel menggunakan rumus Federer (1977) (n-1)(t-1) $>15$ sehingga diperoleh hasil $n=16$. Hasil diperoleh dari pengamatan struktur histologi dan pengukuran ketebalan lapisan korteks dan medulla ovarium kambing PE.

Sampel yang telah diambil selanjutnya difiksasi ke dalam formalin $10 \%$ kemudian diproses di Laboratorium Patologi Balai Besar Veteriner Denpasar. Metode yang digunakan dalam pembuatan sediaan histologi, mengikuti metode yang dilakukan oleh Suwiti et al. (2015). Metode tersebut dilakukan dengan cara: memasukan sampel ke dalam aquades I dan II kemudian didehidrasi dan diclearing dengan satu sesi larutan formalin 10\% I, formalin $10 \%$ II, formalin 10\% III, alkohol $70 \%$, alkohol $96 \%$, alkohol absolute I, alkohol absolute II, alcohol absolut III, xylol I, xylol II, xylol III, toluene I, toluene II, toluene III, paraffin cair selama \pm 23 jam, selanjutnya dibloking menggunakan alat embedding set yang sudah dituangi paraffin dan didinginkan selama \pm 30 menit di dalam lemari es. Lalu diseksioning dengan mikrotom setebal \pm 3-4 mikron dan diletakkan pada objek gelas, sehingga jaringan menempel dengan sempurna, 
kemudian dilakukan pewarnaan hematoksilin eosin.

Metode Harris-Hematoksilin Eosin melalui cara direndam dalam xylol I, II, III masing - masing selama 5 menit, kemudian direndam dalam alkohol absolut I dan II masing - masing selama 5 menit. Setelah itu direndam dalam aquadest selama 1 menit lalu direndam dalam Harris-Hematoksilin selama 15 menit, kemudian direndam dalam aquadest selama 1 menit dan 15 menit. Setelah itu direndam dalam eosin selama 2 menit yang dilanjutkan dengan direndam dalam alkohol 96\% I selama 3 menit, alkohol 96\% II selama 3 menit, dan alkohol absolut III dan IV masing- masing selama 3 menit kemudian preparat dibilas dengan xylol I dan II masing-masing selama 5 menit. Tahapan terakhir yaitu menggunakan kanada balsam berisi entellan sebagai perekat (mounting) dan didiamkan hingga kering.

\begin{abstract}
Hasil diperoleh dari pengamatan struktur histologi dan pengukuran ketebalan lapisan korteks dan medulla. Pengamatan struktur histologi menggunakan zeiss teaching mikroskop, pembesaran lensa objektif 10x, 40x, dan 100x. Pengukuran histomorfometri dilakukan dengan pembesaran $10 \mathrm{x}$ dan dilakukan pada 5 lapang pandang dan dirata-ratakan.

Data dari struktur histologi dianalisis dengan deskriptif kualitatif. Data histomorfometri dari tebal lapisan korteks dan medulla dianalisis dengan menggunakan Uji T.
\end{abstract}

\title{
HASIL DAN PEMBAHASAN
}

Hasil pengamatan struktur histologi ovarium kambing peranakan etawah disajikan pada Gambar 1. Struktur histologi ovarium kambing peranakan etawah terdiri dari 2 lapisan yaitu lapisan korteks dan medulla.

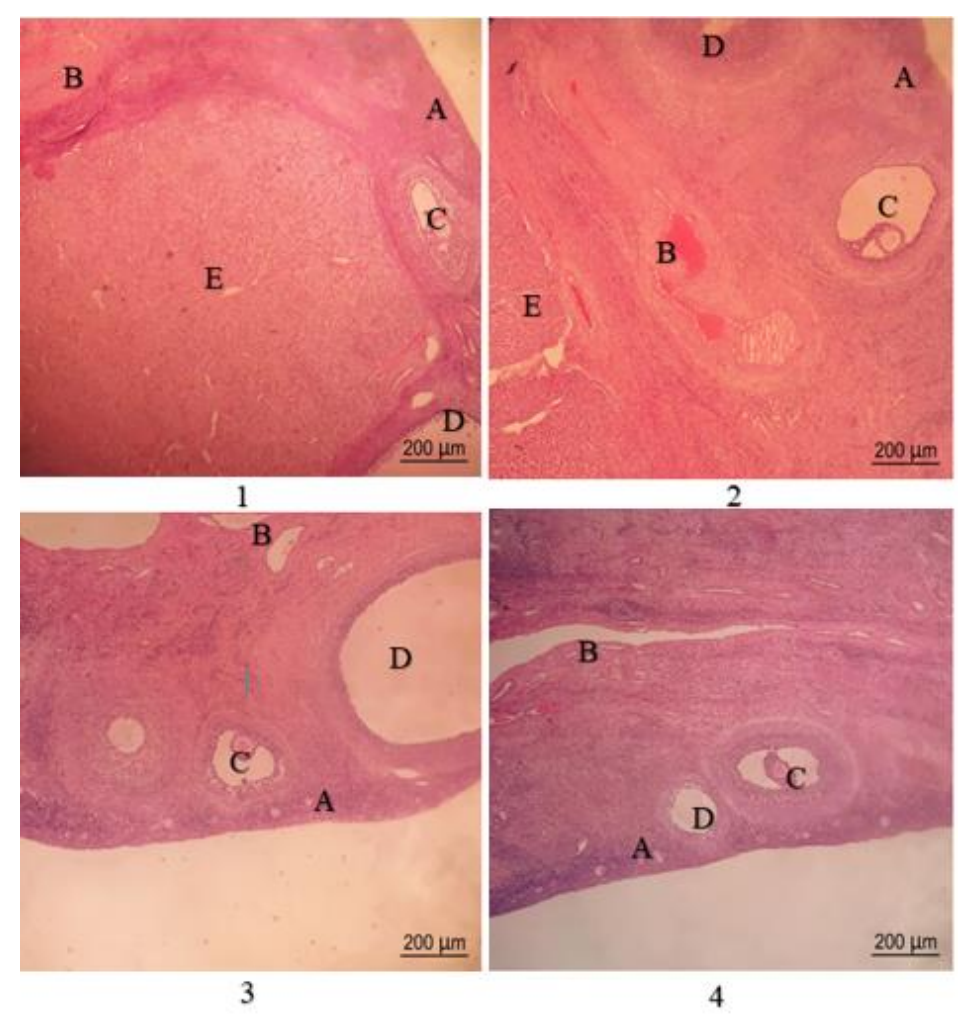

Gambar 1. Struktur histologi ovarium kambing PE dewasa dan muda (HE, 40x). dewasa kanan (1), dewasa kiri (2), muda kanan (3), muda kiri (4). Ket: A. Medulla ovarium, B. Korteks ovarium, C. Folikel tertier, D. Atresi folikel, E. Corpus luteum. 
Lapisan korteks berada pada bagian lateral banyak ditemukannya berbagai tahapan perkembangan folikel, folikel yang atresi, folikel yang tumbuh sehat, dan corpus albicans. Lapisan medulla yang berada pada bagian medial, terdiri dari jaringan ikat longgar dan banyak ditemukan pembuluh darah dan saraf.

Ovarium kambing peranakan etawah sacara mikroskopik memiliki karakteristik histologi dan jumlah folikel dari berbagai tahapan perkembangan folikel yang sangat dinamis dengan jumlah yang bervariasi. Hasil Perhitungan jumlah folikel dari berbagai tahapan perkembangan folikel ovarium kambing peranakan etawah disajikan pada Table 1.

Tidak ada perbedaaan jumlah folikel ovarium kanan dan kiri $(\mathrm{P}>0.05)$. Pada ovarium dewasa kanan dengan ovarium muda kanan tidak menunjukan perbedaan yang signifikan $(\mathrm{P}>0.05)$, tidak ada perbedaan jumlah folikel ovarium dewasa kiri dengan ovarium muda kiri $(\mathrm{P}>0.05)$.

Tabel 1. Rataan Hasil Perhitungan Jumlah Folikel Ovarium Kambing Peranakan Etawah.

\begin{tabular}{llll}
\hline Folikel & Posisi & Dewasa & Muda \\
\hline F. primer & Kanan & $80.25 \pm 33.37^{\mathrm{aa}}$ & $92.75 \pm 17.63^{\mathrm{ab}}$ \\
& Kiri & $64.93 \pm 23.51^{\mathrm{aa}}$ & $90.68 \pm 12.19^{\mathrm{aa}}$ \\
\hline F. sekunder & Kanan & $1.25 \pm 1.12^{\mathrm{cc}}$ & $1.06 \pm 0.85^{\mathrm{cc}}$ \\
& Kiri & $1.12 \pm 0.71^{\mathrm{cc}}$ & $0.93 \pm 0.92^{\mathrm{cc}}$ \\
\hline F. tertier & Kanan & $1 \pm 1.09^{\mathrm{ee}}$ & $0.75 \pm 0.77^{\mathrm{ee}}$ \\
& Kiri & $0.93 \pm 0.85^{\mathrm{ee}}$ & $0.62 \pm 1.02^{\mathrm{ee}}$ \\
\hline Corpus luteum & Kanan & $1.06 \pm 0.68^{\mathrm{gg}}$ & $0 \pm 0^{\mathrm{gh}}$ \\
& Kiri & $1 \pm 0.73^{\mathrm{gg}}$ & $0 \pm 0^{\mathrm{gh}}$ \\
\hline Atresi folikel & Kanan & $3.06 \pm 1.38^{\mathrm{pp}}$ & $4.06 \pm 2.04^{\mathrm{pp}}$ \\
& Kiri & $2.87 \pm 2.44^{\mathrm{pp}}$ & $3.18 \pm 2.19^{\mathrm{pp}}$ \\
\hline Corpus albicans & Kanan & $0.68 \pm 0.7^{\mathrm{xx}}$ & $1.62 \pm 2.3^{\mathrm{xy}}$ \\
& Kiri & $0.62 \pm 0.61^{\mathrm{xx}}$ & $1.06 \pm 0.57^{\mathrm{xx}}$ \\
\hline
\end{tabular}

Ket: Huruf pertama yang berbeda pada satu kolom menunjukan berbeda nyata $(\mathrm{P}<0.05)$, huruf pertama yang sama pada satu kolom menunjukan tidak berbeda nyata $(\mathrm{P}>0.05)$. Huruf kedua yang berbeda pada satu baris menunjukan berbeda nyata $(\mathrm{P}<0.05)$, sedangkan huruf kedua yang sama pada satu baris menunjukan tidak berbeda nyata $(\mathrm{P}>0.05)$.

Struktur histologi folikel primer (Gambar 2) terdiri dari oosit dikelilingi oleh satu atau dua lapis sel granulosa yang berbentuk kuboid. Folikel sekunder tersusun dari oosit yang dikelilingi dua sampai lima lapis atau lebih sel granulosa berbentuk kuboid, dengan zona pelusida tipis hingga sedikit menebal, dan ditemukan sel-sel teka (Gambar 3).

Struktur histologi folikel tertier terdiri dari oosit dilapisi lebih dari lima lapis sel granulosa berbentuk kuboid, terbentuknya antrum folikuli sampai semakin membesar, zona pelusida menebal, oosit mulai bergerak ke bagian tepi hingga di tepi (Gambar 4).
Struktur histologi corpus luteum memiliki ciri sel-sel granulosa mengalami pembesaran dengan bentuk yang tidak beraturan, sel teka mengalami sedikit pembesaran dan warna lebih gelap dari sel granulosa lutein (Gambar 5).

Struktur histologi atresi folikel di tandai dengan adanya sel-sel granulosa yang mengalami piknotis dan luruhnya sel-sel granulosa ke bagian antrum (Gambar 6). Regresi corpus luteum, menyisakan jaringan parut yang disebut corpus albicans yang tersusun atas jaringan ikat kolagen dengan beberapa jaringan fibroblast (Gambar 7). 

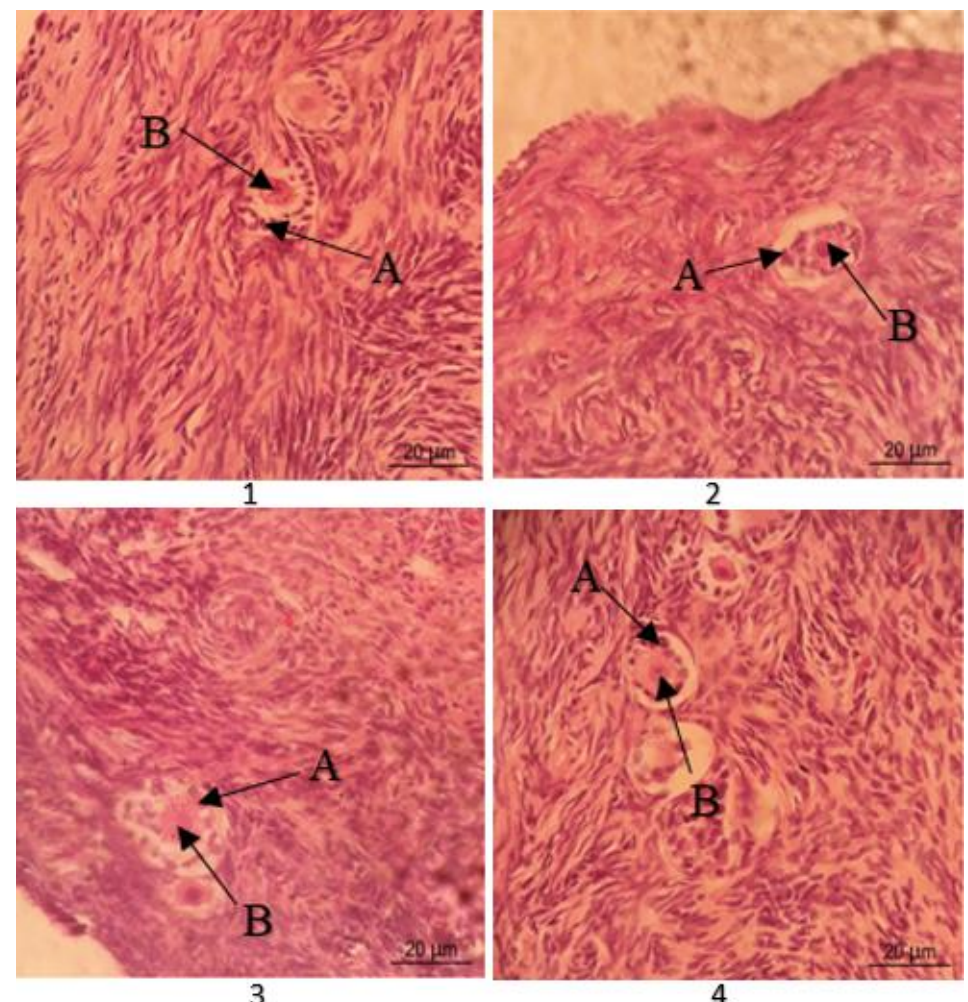

Gambar 2. Struktur histologi folikel primer kambing PE (HE, 400x). Dewasa kanan (1), dewasa kiri (2), muda kanan (3), muda kiri (4). Ket: A. Sel Granulosa, B. Oosit.
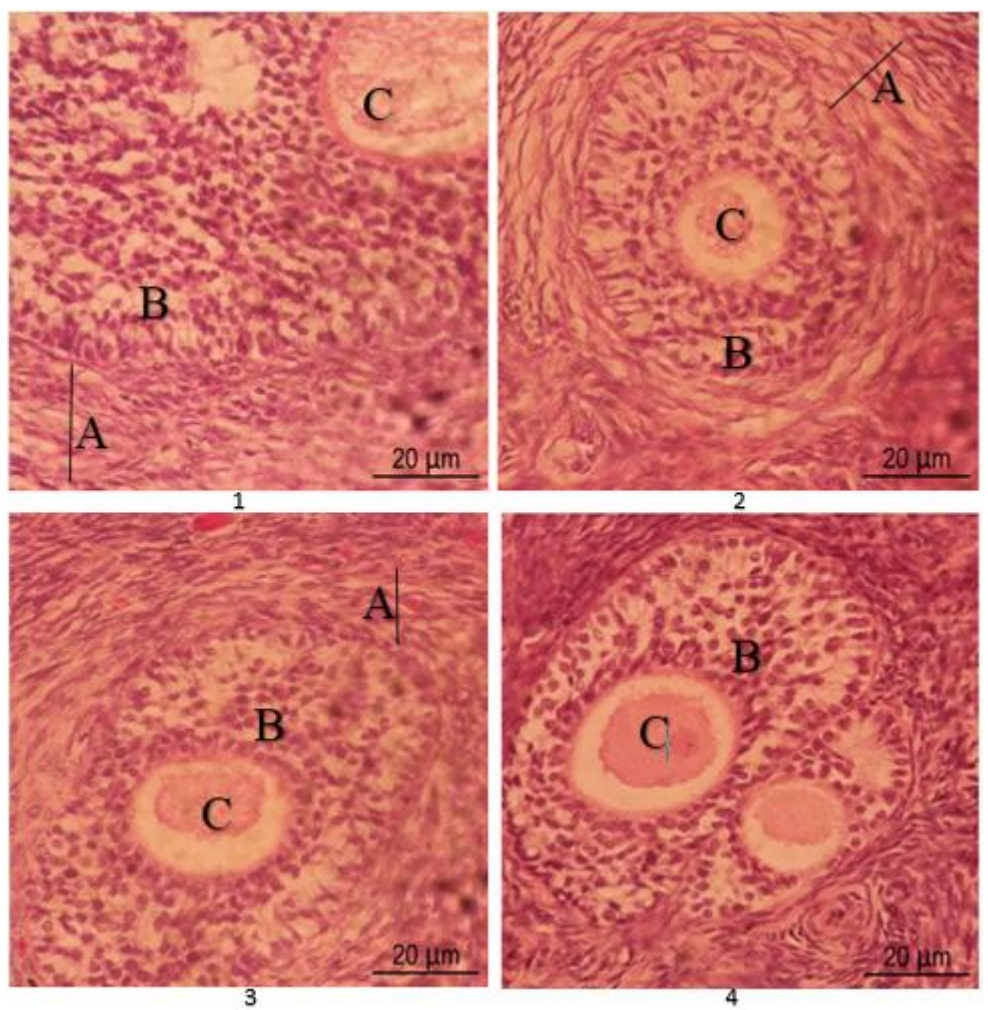

Gambar 3. Struktur histologi folikel sekunder kambing PE (HE, 400x). Dewasa kanan (1), dewasa kiri (2), muda kanan (3), muda kiri (4). Ket: A. Sel teka B. Sel granulosa C. Oosit 


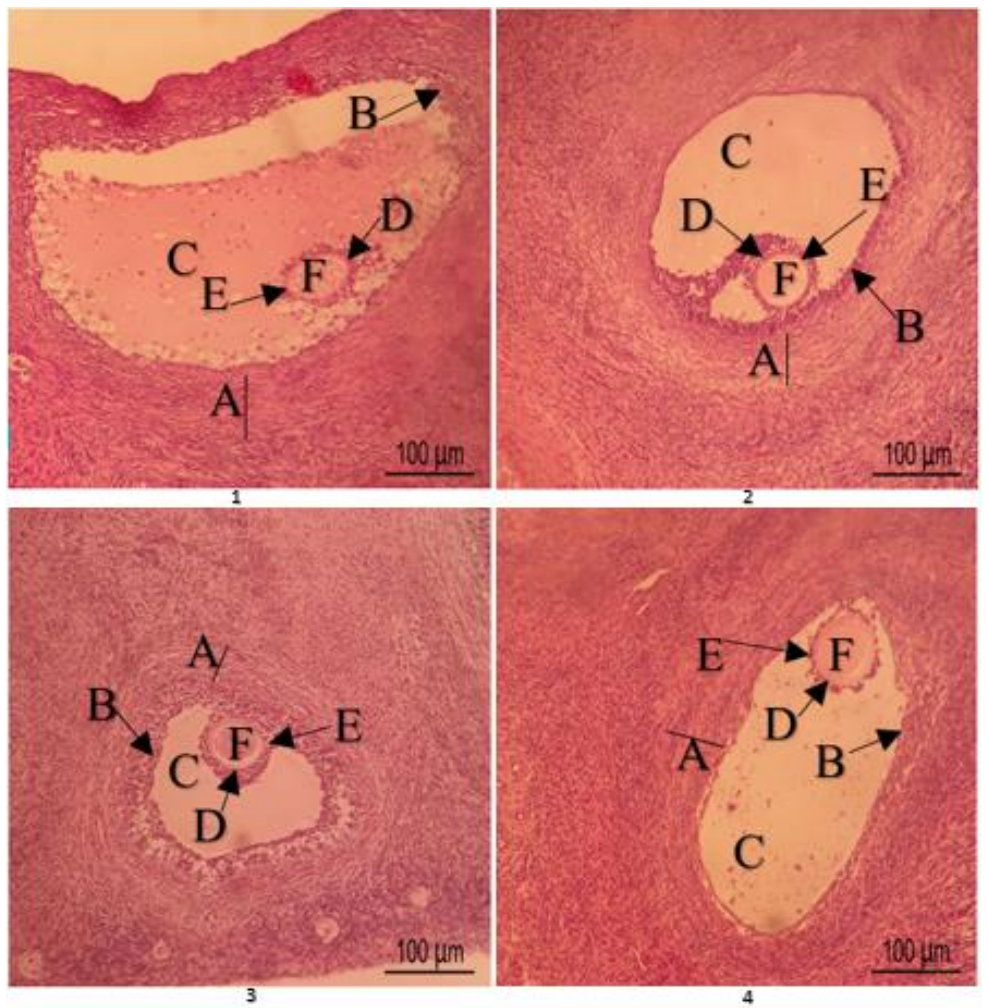

Gambar 4. Struktur histologi folikel tertier kambing PE (HE, 100x). Dewasa kanan (1), dewasa kiri (2), muda kanan (3), muda kiri (4). Ket: A.Sel teka B. Sel granulosa C. Antrum folikuli D. Corona radiata E. Zona pelusida F. Oosit.

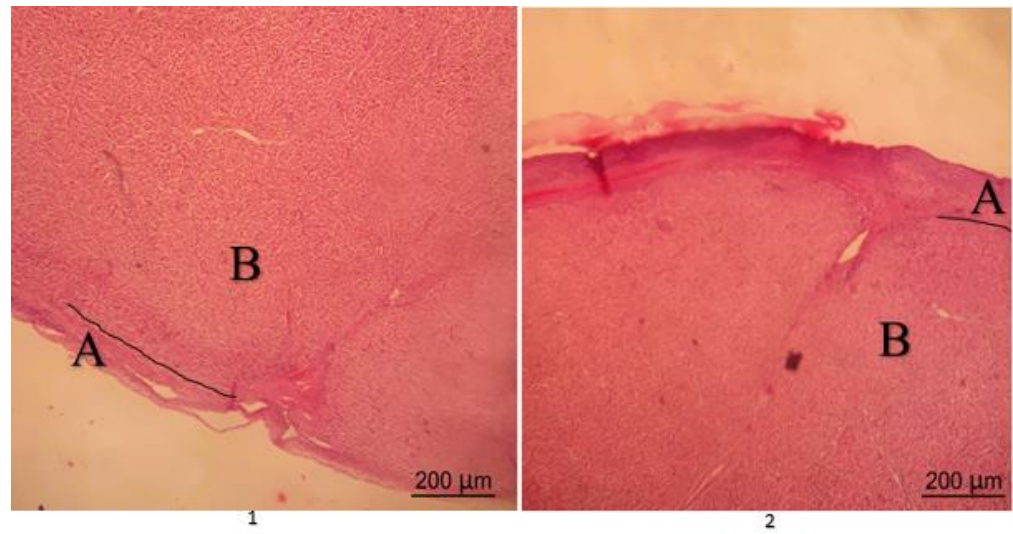

Gambar 5. Struktur histologi corpus luteum kambing PE (HE, 40x). Dewasa kanan (1) dan dewasa kiri (2). Ket: A. Membran basal B. Sel granulosa lutein. 

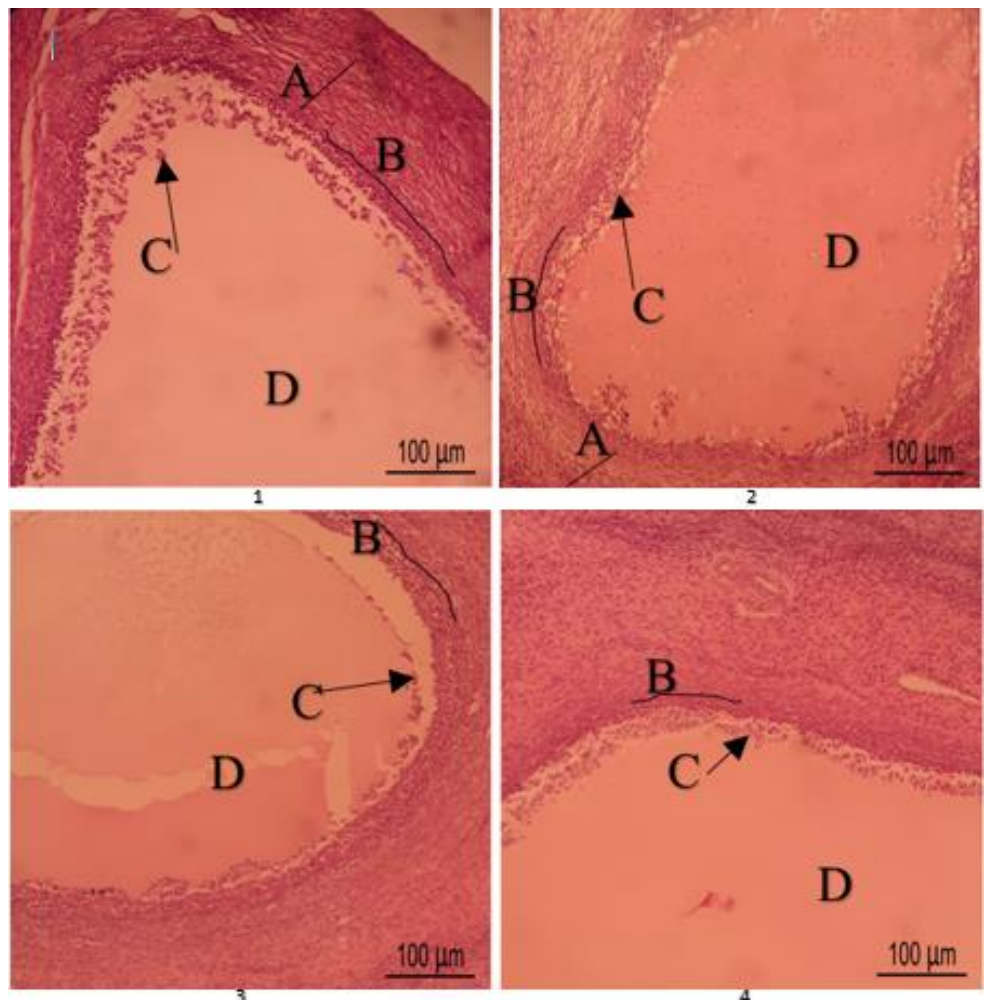

Gambar 6. Struktur histologi atresi folikel kambing PE (HE, 100x). Dewasa kanan (1), dewasa kiri (2), muda kanan (3), muda kiri (4). Ket: A. Sel teka B. Membran basal C. Sel granulosa D. Antrum folikel.
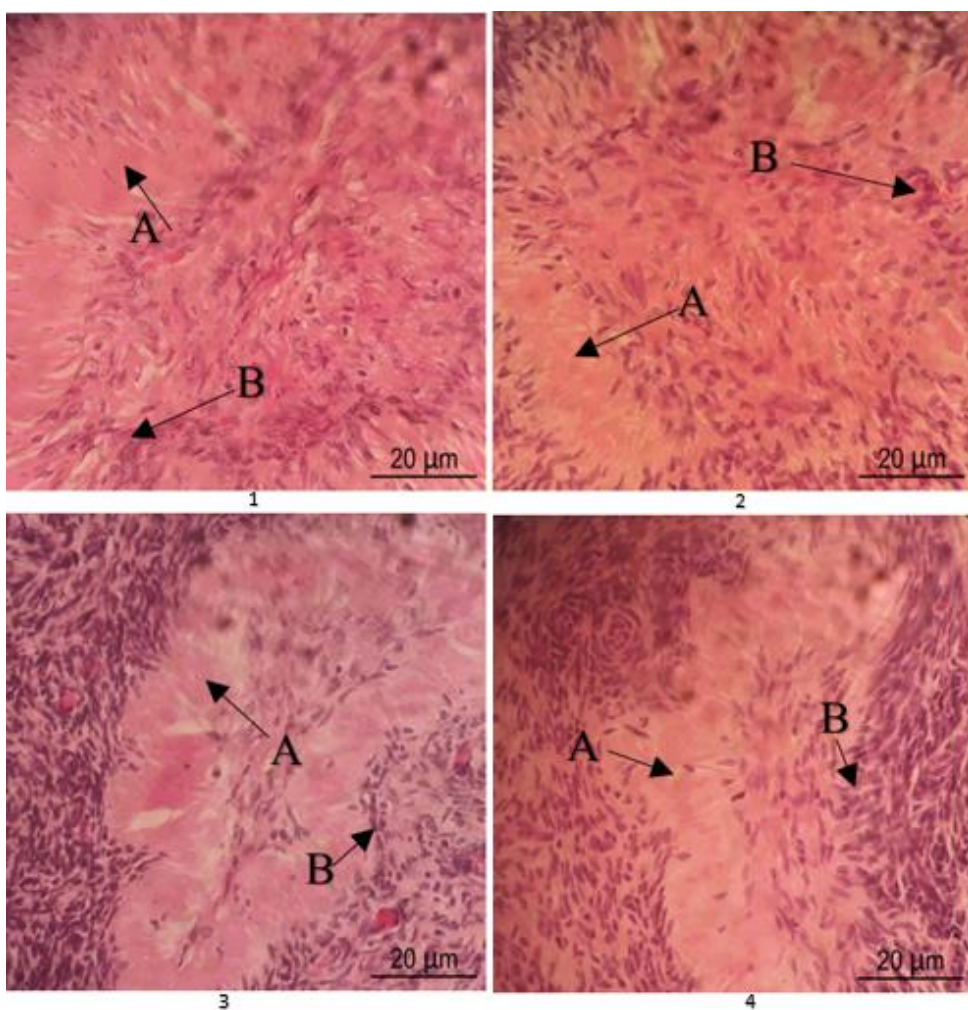

Gambar 7 Struktur histologi corpus albicans kambing PE (HE, 400x). Dewasa kanan (1), dewasa kiri (2), muda kanan (3), muda kiri (4). Ket: A. Jaringan ikat kolagen B. Fibroblas 
Tabel 2. Rataan hasil pengukuran ketebalan korteks dan medulla ovarium kambing peranakan etawah

\begin{tabular}{|c|c|c|c|}
\hline Lapisan & Posisi & Dewasa & Muda \\
\hline \multirow[t]{2}{*}{ Korteks } & Kanan & $3804.94 \pm 378.08^{\text {aa }}$ & $1239.42 \pm 387.77^{\mathrm{ab}}$ \\
\hline & kiri & $3328.81 \pm 278.81^{\text {aa }}$ & $1073.52 \pm 201.16^{\mathrm{ab}}$ \\
\hline & kanan & $876.42 \pm 51.81^{\mathrm{xx}}$ & $685.56 \pm 70.48^{x y}$ \\
\hline Medulla & kiri & $694.70 \pm 66.65^{\mathrm{xx}}$ & $657.61 \pm 55.50^{x y}$ \\
\hline
\end{tabular}

Ket: Huruf pertama yang berbeda pada satu kolom menunjukan berbeda nyata $(\mathrm{P}<0.05)$, huruf pertama yang sama pada satu kolom menunjukan tidak berbeda nyata $(\mathrm{P}>0.05)$. Huruf kedua yang berbeda pada satu baris menunjukan berbeda nyata $(\mathrm{P}<0.05)$, sedangkan huruf kedua yang sama pada satu baris menunjukan tidak berbeda nyata $(\mathrm{P}>0.05)$.

\section{Histomorfometri ovarium kambing peranakan etawah}

Hasil pengukuran histomorfometri ovarium kambing peranakan etawah disajikan pada Tabel 2. Tidak ada perbedaan ketebalan korteks dan medulla ovarium kanan dan kiri $(\mathrm{P}>0.05)$. Sedangkan ovarium kambing $\mathrm{PE}$ dewasa bagian korteks dan medulla lebih tebal dibandingkan yang muda $(\mathrm{P}<0.05)$.

Struktur histologi ovarium peranakan etawah relatif sama dengan hewan ruminansia lainnya seperti sapi dan domba (Kimura et al., 2014). Ovarium kambing peranakan etawah terdiri dari dua lapisan yaitu korteks dan medulla. Pada lapisan korteks banyak ditemukan folikel, sedangkan lapisan medulla ditemukan pembuluh darah dan jaringan ikat longgar. Ovarium kambing PE kiri dan kanan mempunyai ketebalan yang sama. Ketebalan ovarium kiri tidak berbeda dengan yang kanan tetapi, pada yang dewasa lebih tebal dibandingkan dengan yang muda $(\mathrm{P}<0,05)$ (Sobari, 2012). Hal ini dikarenakan inervasi saraf dan pembuluh darah ke ovarium kanan dan kiri sama. Hasil penelitian berbeda ditemukan pada sapi aceh dimana ovarium kanan lebih besar dibandingkan yang kiri (Jalaluddin, 2014), hal ini disebabkan karena aktivitas ovarium kanan dan kiri berbeda. Ketebalan korteks dan medulla pada kambing PE dewasa dengan yang muda ditemukan perbedaan yang nyata $(\mathrm{P}<0.05)$. Hal ini disebabkan besarnya ukuran ovarium berkolerasi dengan umur dan ukuran tubuh ternak. Perbedaan ukuran ovarium dapat juga disebabkan umur dewasa dan sudah pernah melahirkan (Govur et al, 2015) Semakin besar ukuran ovarium maka semakin besar aktivitasnya, hal ini disebabkan sekresi hormon estrogen dan progesterone yang mempunyai peranan besar pada siklus estrus. Bertambahnya umur dan jumlah anak yang dilahirkan, tahapan siklus reproduksi, spesies akan berpengaruh terhadap ukuran dan berat ovarium.

Jumlah folikel yang tumbuh pada ovarium kambing PE umur dewasa dan muda tidak menunjukan perbedaan $(\mathrm{P}>0.05)$. Hal ini disebabkan kambing muda umur 5-12 bulan sudah memasuki dewasa kelamin (Sodiq dan Abiding, 2002). Struktur histologi ovarium kambing PE yang diamati melalui perkembangan folikel ditunjukan adanya folikel primordial yang terdiri dari oosit dilapisi satu sel granulosa dari berbentuk transisi antara pipih dan kuboid hingga berbentuk pipih (Cushman et al., 2000). Folikel primordial berkembang ditandai dengan adanya perubahan dari satu lapis sel granulosa berbentuk pipih menjadi oosit dikelilingi satu sampai dua lapis sel granulosa berbentuk kuboid pada tahap ini disebut folikel primer (Gambar 2) (Cushman et al., 2000).

Folikel primer berkembang menjadi folikel sekunder yang ditandai dengan adanya dua sampai lima lapis sel granulosa, bertambahnya diameter folikel, dan adanya zona pelusida, dimana zona pelusida 
merupakan suatu glikoprotein yang disekresikan oleh oosit dan sel granulosa (Gambar 3) (Wu et al., 2004). Folikel sekunder (folikel preantral) berkembang menjadi folikel tertier yang ditandai dengan adanya lima sampai lebih sel granulosa berbentuk kuboid, zona pelusida semakin menebal, memiliki antrum folikuli dan sel theca (Gambar 4) (Cushman et al., 2000). Pada tahapan selanjutnya antrum folikuli semakin membesar sehingga oosit terdesak ke pinggir dan dinding folikel semakin menipis kemudian menjadi stigma yang akan robek saat ovulasi (Hafez dan hafez, 2000). Pada ovarium dewasa ditemukan corpus luteum sedangkan pada ovarium muda tidak, hal ini disebabkan karena perbedaan fase antara fase luteal dengan folikuler, yang disebabkan semakin dewasa umur ternak maka semakin optimal fungsi organ reproduksi (Demark, 1985).

Pada ovarium kambing $P E$ juga ditemukan atresi folikel yang ditandai adanya sel-sel granulosa yang mengalami piknotis dan luruhnya sel granulosa ke antrum folikuli (Gambar 6). Atresi folikel terjadi akibat kelebihan proses metabolik pada folikel, dimana hasil metabolik yang berlebihan akan bersifat racun pada sel-sel folikel yang menyebabkan kematian sel-sel folikel dan tidak dapat berkembang (Fortune, 1994).

Tidak ada perbedaan jumlah folikel kanan dan kiri $(\mathrm{P}>0,05)$, tetapi jumlahnya sangat bervariasi. Hal ini disebabkan aktivitas ovarium kanan dan kiri sama (Hammy et al., 2010). Distribusi perkembangan setiap folikel pada ovarium tidak sama, folikel primer banyak ditemukan pada bagian korteks ovarium, sedangkan untuk folikel sekunder berkembang kearah medulla. Sedangkan folikel tertier kembali mengarah ke korteks, karena terdapat oosit yang hampir matang yang nantinya akan siap di ovulasi. Keadaan ini sama ditemukan pada kancil (Hammy et al., 2010).

\section{SIMPULAN DAN SARAN}

\section{Simpulan}

Struktur histologi ovarium kambing peranakan etawah terdiri atas dua lapisan yaitu korteks dan medulla, dengan tahapan perkembangan, folikel primer, folikel sekunder, foliker tertier, corpus luteum, atresi folikel dan corpus albicans. Medulla terdiri dari jaringan ikat longgar dan banyak ditemukan pembuluh darah dan saraf. Tidak ada perbedaan $(\mathrm{P}>0.05)$ Pketebalan korteks dan medulla ovarium kanan dan kiri. Ketebalan korteks dan medulla kambing Peranakan Etawah dewasa lebih tebal $(\mathrm{P}<0.05)$ dibandingkan dengan yang muda

\section{Saran}

Perlu dilakukan penelitian lebih lanjut mengenai sistem reproduksi betina pada kambing peranakan etawah dari berbagai organ reproduksi lainnya.

\section{UCAPAN TERIMA KASIH}

Penulis mengucapkan terimakasih kepada Bapak Dekan Fakultas Kedokteran Hewan atas fasilitas yang telah diberikan selama penelitian dan kepada semua pihak yang telah membantu dalam penelitian ini, sehingga penelitian ini dapat diselesaikan dan semoga bermanfaat bagi masyarakat.

\section{DAFTAR PUSTAKA}

Choliq, Chusnul, Widodo, Setyo, Sajuthi D, Wijaya A. Wulansari, R., Lelana, A. 2014. Diagnostik Klinik Hewan Kecil: Bab VII Kulit dan Rambut. PT Penerbit IPB Press Edisi I Cetakan Ketiga, Kampus IPB Taman Kencana Bogor.

Cushman RA, Hedgpeth VS, Echternkamp SE, Britt JH. 2000. Evaluation of number of microscopic and macrocospic follicles in cattle selected for twinning. J. Anim. Sci., 78(6): 15641567.

Dellman HD, Esther MD. 1992. Buku Teks Histologi Veteriner. Universitas Indonesia Press. Jakarta 
Denmark VNL, Salisbury GW. 1985. Fisiologi Reproduksi dan Inseminasi Buatan Pada Sapi. Diterjemahkan oleh R. Djanuar. Gadjah mada University Press. Yogyakarta.

Direktorat Jenderal Peternakan dan Kesehatan Hewan. 2016. Statistik Peternakan dan Kesehatan Hewan 2016. Kementerian Pertanian. Jakarta.

Djajanegara A, Setiadi B. 1991. Goat production in Indonesia; in: Goat Reproduction in the Asian Humid Tropics. Proc. Int. Sem. Thailand, Pp. 1-6.

Federer WT. 1997. Experimental Design Theory and Application. $3^{\text {rd }}$ Ed. Oxford and IBH Publishing Co. New Delhi Bombay Calvuta

Fortune JE. 1994. Ovarian follicular growth and development in mammals. Biol. Reprod., 50(2): 225-232.

Govur WA, Rasad SD, Solihati N. 2015. Pengaruh Umur Terhadap Bobot dan Diameter Ovarium Serta Kualitas Oosit Pada Domba Lokal. Faklutas Peternakan Universitas Padjajaran.

Hafez B, Hafez ESE. 2000. Anatomy of Female Reproduction. In Reproduction in Farm Animals. Hafez, B. and E.S.E. Hafez (Eds.). $7^{\text {rd }}$ Ed. Lippincott Williams \& Wilkins, USA.

Hammy, Agungpriyono S, Djuwita I, Prasetyaningtyas WE, dan Nasution. 2010. Karakteristik Histologi Perkembangan Folikel Ovarium Fase Luteal pada Kancil. Institut Pertanian Bogor. Bogor

Jalaluddin M. 2014. Morfometri dan karakteristik histologi ovarium sapi aceh (Bos indicus) selama siklus estrus. J. Med. Vet. 8(1): 66-68.

Kimura J, Sasaki M, Endo E, Fukuta K. 2004. Anatomical and histological characterization of the female reproductive organs of mouse deer (Trangulidae). Plasenta, 25: 705-711.

Sobari I, Trilaksana IGNB, Suatha IK. 2012. Perbedaan aktivitas ovarium sapi bali kanan dan kiri serta morfologi oosit yang dikoleksi menggunakan metode slicing. Indonesia Med. Vet., 1(1): 1-11.

Sodiq A, Abidin Z. 2002. Kambing Peranakan Etawa Penghasil Susu Berkhasiat Obat. Agromedia Pustaka. Jakarta.

Sodiq A. 2010. Pola usaha peternakan kambing dan kinerja produktivitasnya diwilayah eks-Karesidenen Banyumas Jawa-Tengah. Agripet., 10(2): 1-8

Sutama K. 2011. Kambing Peranakan Etawah Sumberdaya Ternak Penuh Berkah. Balai Penelitian Ternak Ciawi Bogor.

Suwiti NK, Setiasih NLE, Suastika IP, Piraksa IW, Susari NW. 2015. Studi histologi usus besar sapi bali. Buletin Vet. Udayana, 2(2): 101-107.

Wu GM, Lai L, McCauley TC, Caamano JN, Cantley T, Rieke A, Murphy CN, Prather RS, Didion BA, Day BN. 2004. Birth of piglets by invitro fertilization of zona-free porcine oocytes. Theriogenology, 62: 1544-1556

Yoyo, Sugiarta M, Pryono A. 2013. The analysis of farmers potency in economic development of local goat in Banyumas Regency. J. Ilmiah Peternakan, 1(2): 619-626. 